\title{
Theory and Practice of Sustainability in Higher Education - From the Perspective of Green University
}

\author{
Ruimin $\mathrm{Mu}$ \\ School of Municipal and Environmental Engineering \\ Shandong Jianzhu University \\ Jinan, China \\ e-mail: ruiminmu@163.com \\ Ping Liu \\ School of Management \\ Shandong University \\ Jinan, China \\ e-mail: liuping_91@163.com \\ Yuntao Song \\ School of Chemistry and Chemical Engineering \\ Shandong University \\ Jinan, China \\ e-mail: ytsong@163.com \\ Dayong Cao \\ Shandong Academy of Environmental Science \\ Jinan, China \\ e-mail: $\underline{\text { cdy19777@,163.com }}$
}

\author{
Liwei Zhan \\ Shandong Environmental Audits and Reception Center \\ of Construction Projects \\ Jinan, China \\ e-mail: 35107861@qq.com
}

Jian Zuo

School of Natural and Built Environments University of South Australia

Adelaide, Australia

line 4: e-mail: jian.zuo@unisa.edu.au

\author{
Rujian Ma \\ School of Energy and Power Engineering \\ Shandong University \\ Jinan, China \\ mrj2005@126.com \\ Xuliang Yuan \\ School of Energy and Power Engineering \\ Shandong University \\ Jinan, China \\ e-mail: yuanxl@sdu.edu.cn
}

\begin{abstract}
Higher education in China has been growing rapidly in recent years. Sustainability in higher education has also achieved much attention. The concept of green university was proposed more than 10 years ago in China. It has received the positive response from colleges and universities, which also achieved further development in theoretical research and practice. The essence of building green university that is to build and operate a university in a way of sustainable development has been widely recognized. The theoretical analysis of the developments, formation of the concept and a field study at the campuses of Shandong University was carried out. The results show that many initiatives have been adopted at Shandong University, such as energy-saving and water-saving measures, waste management, good opportunity for students and the sustainably oriented courses. In order to accelerate the further development of green university, a coordination committee, special fund and training for new staff and the first year students are important and necessary. The theoretical and practical analysis of green university reflects the efforts for a more sustainable higher education in China.
\end{abstract}

Keywords-sustainability; higher education; green university; awareness; China

.
important part of social resources, it has the characteristics
of involves broad, in large quantities and in many forms. It
consumes much resources and discharges pollutant.
Constructing Green University, building green campus can 
promote resource saving, reduce pollutants emissions. It has a great guidance effect on the social and economic development in China.

In 1994, the State Council approved "China's Agenda 21", which put forward the sustainable development strategies, policies and actions [5]. In 1996, the State Council made it clear that policy should be implemented for the sustainable development through science and education. In 1998, Tsinghua university, combining with the "211 project" construction planning, established a comprehensive three-dimensional construction plan of green university, and become the first university put green university in practice in China [3].

There are also many other universities that make contribution to the construction of green university $[6,7]$. In general, the increasingly number of universities put efforts into developing green campus. Last decade has witnessed the significant achievments on green university developement in China, e.g. improved environmental performance, enhanced public awareness, and reduction of operation and maintenance of campus [7]. Following the development of green university, China Green University Network (CGUN) was formed in Tongji University in March 2011, which includes eight universities and two research institutes [8]. As the leading organization of green university development in China, CGUN are working on the fields of inter-university cooperation and experience exchange.

\section{FORMATION OF THE CONCEPT}

Many people do not have the clear understanding of the green university, because there is no universally accepted definition for it. According to Lukman and Glavič (2007), the key elements of green university should include policies, operations, evaluations and optimizations that need to be considered interactively [9]. As a complex system, the following aspects are recognized as important aspects for the sustainable university, i.e. sustainable campus operations, sustainable research, public outreach, cooperation between/among institutions, sustainable curricula and sustainability reporting [10-12]. The Chinese government is actively promoting the concepts and practices of "Resource Efficient University Campuses (REUC)", which is similar as the theme of green university. REUC is helpful for different stakeholders such as university leaders, students and staff to meet the demands of social responsibility at their universities [3]. This can be achieved by a holistic approach to:

- Educating future professionals and enhancing students' skills and knowledge on sustainable development.

- Improving energy efficiency on campus.

- $\quad$ Shifting to renewably generated energy, food and other materials used on and off campuses.

- Increasing the university's social responsibility on environmental protection, et al.

- Broadening the visions/knowledge/opportunities for action on all environmental issues.

From the perspective of a green university and its external relations, green university should stress that they actively participates in the practice of social sustainable development, using his exemplary behavior directly promote the school community to carry out the practice of sustainable development, and through their ability to develop green technology research, spread the concept of sustainable development culture, promote the sustainable development [8]. There are many factors that contribute towards achieving green university. These factors broadly fit into seven groups, i.e. management systems, environmental sustainability, sustainable curricula, research and development, staff development and rewards, student opportunities and social responsibility [3].

\section{RESEARCH METHODOLOGY}

The aim of this research is to investigate green university practices in China. A case study approach is employed to fulfill this aim. The case study approach is suitable for how and why type of research questions. As this research aims for investigating how green university is practiced in China, case study is an appropriate research method.

Shandong University (SDU) is selected as the case to be studied. SDU was founded in 1901, located in Jinan, the capital city of Shandong Province. It has two branches at Weihai city and Qingdao city. There are 6 campuses at Jinan, which cover an area of 3,849 square $\mathrm{km}$. The campuses are comprised of 6 divisions, 31 schools/colleges and a graduate school. In 2013, there are 10,100 new enrolments and total of more than 6,000 fulltime students registered on campus.

\section{GREEN UNIVERSITY IN PRACTICE AT SDU}

Shandong University hasSome large scale questionaire sueveys have been done to examine the development of green university at SDU. The top priorities for higher education for sustainable development from the students' perceptions are generally environmentally oriented $[1,3]$. A field study was carried out at the campus of SDU recently. This field study mainly focus on SDU's existing integrated efforts on greening their campus at the actural impletation level.

\section{A. Eergy-saving}

Solar water heater and solar PV. The solar heater system is located on the roof of the public bathroom. This installation will save 700 tonnes of coal equivalent (tce) every year. There are solar PV systems in some public squares, such as the main building square in the Qianfoshan campus.

Public transportation between campuses. There are 6 campuses at Jinan. The distance between the campuses is as far as 12 kilometers. The university arranged the bus with fixed time schedule to connect different campuses.

Automatic water heater. The energy saving water heater has the automatic time switch. When the water gets boiled, the water heater will automatic stop heating.

Voice control and light control lamps. Most of the street lamp and lamps in buildings are light control and voice control respectively.

Sensor Controls. In the teaching buildings, the sensor lights replaced the traditional switchers. When there are students studying in the rooms, the lights turn on automatically. Otherwise, it will be turned off. The new library in Xinglongshan Campus installed a door with distance sensor. The door open automatically when people come nearby. 
Double glazing windows. In the office rooms, teaching rooms and libraries, the double glazing windows are installed. This kind of windows can prevent the heat lose effectively.

Green roof. On the roof of the canteen room, lab building and library, there are a green roof planting. This is helpful for keeping room temperature and greening the landscape of the campus.

Automatic elevator. In most public buildings, the elevators are installed with energy-sensing devices. When no one takes the elevator, the elevator is not moving.

Limits of free electricity. "Energy Management Measures of Shandong University" came into effective since 2006. Free electricity monthly for under graduates, post graduates and $\mathrm{PhD}$ candidates is $5 \mathrm{kWh}, 8 \mathrm{kWh}$ and $16 \mathrm{kWh}$, respectively. Extra electricity beyond the limits will be charged. This will encourage the energy saving behavior in students.

Energy quota management. SDU released "the control standards of heating energy consumption", "incentives and disincentives for school bus drivers" and other related quota management methods for energy-saving.

Air conditioning frequency transformation. In order to reduce electricity consumption, the air conditioning system in the central office building, functional materials building and building of nursing school are reformed with frequency transformation.

Renovation of existing buildings for energy-saving. The existing buildings in SDU were built during 1931 and 2013 , with a total construction area of more than 1 million $\mathrm{m}^{2}$. The renovation of existing buildings is getting significant effect on energy-saving.

\section{B. Water-saving}

Water recycle. There is a sewage treatment station at Xinglongshan campus. Most treated water pumped to the artificial lake as landscape water. The rest is used for watering trees and plants in the campus.

Limits of free water consumption. Previously mentioned "Energy Management Measures of Shandong University" also required that the free water consumption monthly is 2 tones per student.

Induction flushes toilets. All toilets in the public buildings at SDU are installed induction flushes instruments.

Water-saving faucets. The traditional public water-taps are replaced by water-saving instruments.

\section{Waste management}

Green classified dustbin. The 6 campuses of SDU put green classified dustbin in place. The garbage can be divided by recyclable, non-recyclable and hazards waste.

Hazards waste management. All the hazards waste from labs, teaching rooms and dustbin are transported to the qualified designated company for safe treatment.

Waste minimization measures. The university office outlined the requirements for minimizing waste, such as paperless office, double-sided printing, and "clear your plate "campaign.

\section{Green curricula}

Trans-disciplinary course on sustainability. There are about 20 sustainability oriented courses for the students from different schools at SDU, such as "Energy and Environment", "Introduction to Environment", "Energy management Engineering", "Cleaner Production and Circular Economy", "New and Renewable Energy".

Embed sustainability in courses. All students majoring in science and technology, and part students majoring in humanities, arts and medicine having the courses with sustainability embedded.

\section{E. Students' opportunity for green university}

Contest on energy saving and emission reduction. Students' contest on energy saving and emissions reduction has been held annually at SDU since 2010. The fifth contest ended successfully on 26th April, 2014. This contest attracts the attention of students from all over the university.

Sustainability oriented social practice. SDU organize sustainability oriented social practice on each summer vacation and winter vacation. This is helpful for the students to combine their theoretical study and practical capability.

Student's societies on green university. There are more than 70 student's societies of the university level at SDU. Some of them are focus on sustainable campus, such as the society of environmental protection, the society of green ecology, the society of water culture, et al.

\section{F. Propaganda for sustainable development}

Green tips. In the campus, as long as there is the lawn, there is a green basic tip. This tip can improve people's environmental protection consciousness and prevent people trample on the lawn. There are also these kinds of tips beside the water-taps for saving water, tips besides switchers for turn off the light of electric fan, tips in the canteen rooms for saving food.

Large-scale publicity on special days. On the World Environment Day, World Earth Day, World Water Day, and other special days with relation to environment and ecology, SDU holds different activities to call the attention of ecological environment.

\section{G. Limitations for green university development}

SDU has a lot of achievements on green university construction. However, compared with the factors listed in the survey [3], there are still much rooms for further improvement. Firstly, SDU has not established a sustainability coordination committee till now, which has been deemed as an important aspect during a university's development, especially at the stage of acting different future strategies [13]. Secondly, the fund for the research, teaching and activities on green university is not provided. SDU should fill this gap as soon as possible. Thirdly, sustainability oriented training for new staff and the first year students are not available so far. The provision of education on principles of green university is an effective approach for newcomers.

\section{CONCLUSIONS}

Sustainable development is an important strategy in China, especially under the context of rapid urbanization and fast economic development. Higher education plays a vital role for achieving sustainable development at the macro level. It is imperative to investigate how to improve the sustainability performance in this particular sector. The 
development of green university is one of the important factors. Green university plays a crucial role in realizing the goals, since the influence of university is significant and more and more citizens would have their college life in China.

Nowadays, the awareness of students in green university is obviously strengthened. Most of them have a basic knowledge of energy conservation and emission reduction. This research revealed SDU's existing integrated efforts on green university construction at the actural impletation level. These efforts including energysaving, water-saving, waste management, green curricula, students opportunity and propaganda. The rooms for further development of green university lies in establishing a sustainability coordination committee, arranging special fund and the training for new staff and the first year students.

\section{ACKNOWLEDGMENT}

This research is supported by National Natural Science Foundation (41301640, 41471461), Award Fund for Young Scientists of Shandong Province (BS2012SF015), Humanities \& Social Sciences Project of Shandong Province (14-ZZ-JG-02), Soft Science Research Plan of Shandong Province (2014RKE27057, 2014RKE27058) and The Development Program of Application- Oriented Talent Training for Environmental Engineering Specialty, Shandong Province.

\section{REFERENCES}

[1] X.L. Yuan, and J. Zuo, "Transition to low carbon energy policies in China-from the Five-Year Plan perspective," Energ Policy, vol. 39, Jun. 2011, pp.3855-3859.

[2] A.K. Jorgenson, A. Alekseyko, and V. Giedraitis, "Energy consumption, human well-being and economic development in central and eastern European nations: A cautionary tale of sustainability," Energy Policy, vol.66, Mar. 2014, pp.419-427.

[3] X.L. Yuan, J. Zuo, and D. Huisingh, "Green Universities in China What Matters?" Journal of Cleaner Production, vol. 61, Dec. 2013, pp.36-45.

[4] X.L. Yuan, and J. Zuo, "A Critical Assessment of the Higher Education for Sustainable Development from Students' Perspectives- a Chinese Study," Journal of Cleaner Production, vol. 48, Jun. 2013, pp.108-115.

[5] China State Council, China's Agenda 21. http://www.acca21.org.cn /index.asp

[6] H. Tan, S. Chen, Q. Shi, and L. Wang, "Development of green campus in China," Journal of Cleaner Production, vol. 64, Feb. 2014, pp. 646-653.

[7] Y. Geng, K. Liu, and Xue, B., T. Fujita, "Creating a "Green University' in China: a case of Shenyang University," Journal of Cleaner Production, vol. 61, Dec. 2013, pp.13-19.

[8] China Green University Network, Introduction to China Green Uni versity Network. http://www.cgun.org/content.aspx?info $1 \mathrm{~b}=57 \& \mathrm{fl}$ $\mathrm{ag}=57$

[9] R. Lukman, and P. Glavič, "What are the key elements of a sustainable university?," Clean Technologies and Environmental Policy, vol. 9, May. 2007, pp.103-114.

[10] T. Wright, "Definitions and frameworks for environmental sustainability in higher education," Higher Education Policy, vol. 15, Jun. 2002, pp.105-120.

[11] J. Fien, "Advancing sustainability in higher education: Issues and opportunities for research," Higher Education Policy, vol. 15, Jun. 2002, pp.143-152.

[12] R. Lozano, "Incorporation and institutionalization of SD into universities: breaking through barriers to change," Journal of Cleaner Production, vol. 14, Mar. 2006, pp.787-796.

[13] A. Lidgren, H. Rodhe, and D. Huisingh, "A systemic approach to incorporate sustainability into university courses and curricula,' Journal of Cleaner Production, vol.14, Mar. 2006, pp.797-809. 